\title{
Use of the Ovesco remOVE DC cutter to trim a metal biliary stent with excess length in the duodenum allowing biliary access for ERCP
}

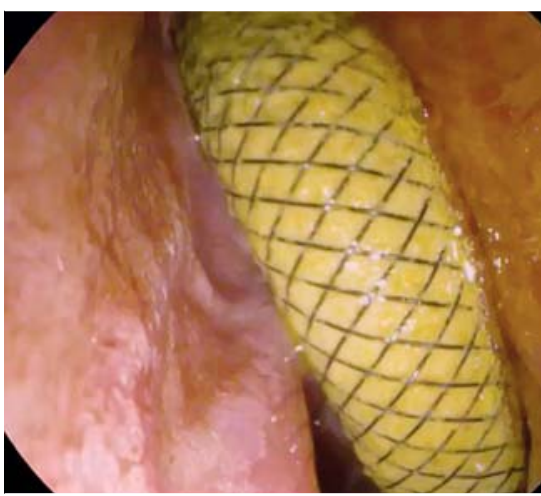

- Fig. 1 Endoscopic view showing the overlapping biliary stent extending distally into the duodenum.

A 78-year-old woman presented with jaundice and cholangitis, having presented 3 years previously with jaundice and hilar stricturing to a hospital elsewhere. The previous episode had been managed as a suspected cholangiocarcinoma with percutaneous transhepatic drainage followed by the insertion of overlapping self-expanding metal stents (SEMSs) extending from the hilum into the duodenum. The stricture had not progressed during 3 years of follow-up and we assessed this to be a benign post-cholecystectomy stricture.

Computed tomography (CT) scanning revealed the overlapping biliary SEMSs, which were obstructed by soft tissue, and multiple stones within and proximal to the stents. Index endoscopic retrograde cholangiopancreatography (ERCP) identified a long portion of stent extending distally into the duodenum and precluding cannulation ( $>$ Fig. 1 ). Attempts to cannulate through the side of the SEMS were unsuccessful owing to the tight overlapping mesh. The distal stent was not removable. The patient was considered unsuitable for surgery and likely to require future biliary interventions, so improved ERCP access was therefore required.

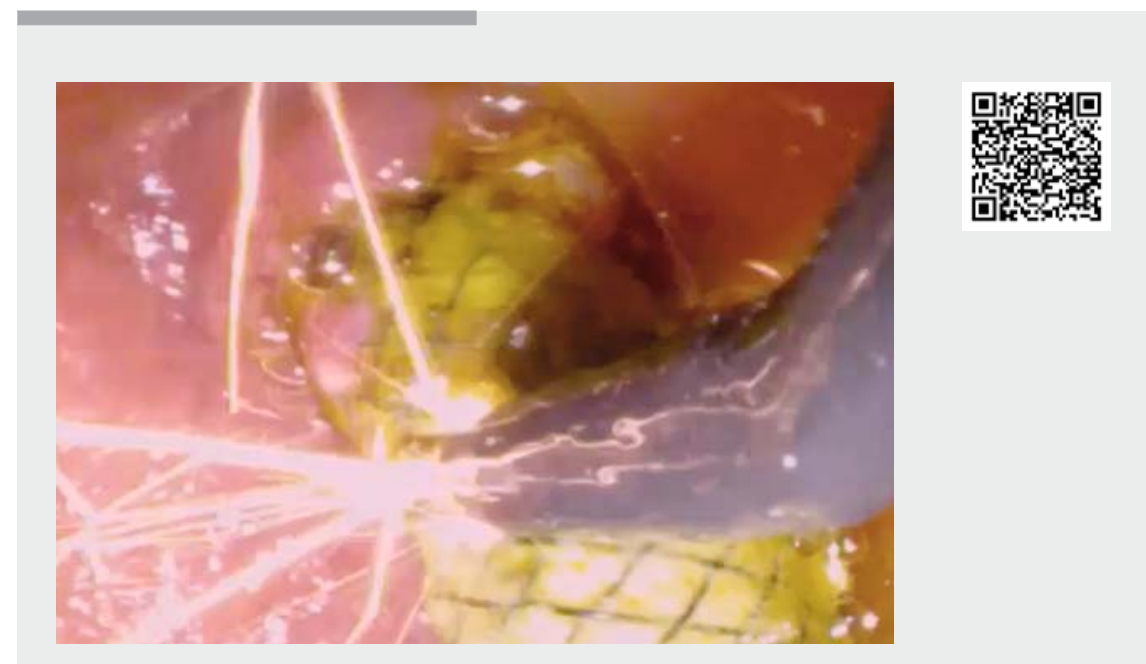

Video 1 The reMOVE DC cutter is used to trim the length of a biliary stent that was extending distally and precluding cannulation at endoscopic retrograde cholangiopancreatography.

A repeat ERCP was performed using a standard duodenoscope (ED34-i10T; Pentax, Tokyo, Japan). The remOVE DC Cutter and the remOVE DC Impulse medical electrical device (Ovesco Endoscopy AG, Tübingen, Germany) were used to circumferentially cut the SEMS, leaving only a short stent portion protruding from the ampulla, which thereby allowed easy ERCP access ( $\triangleright$ Video 1 ). Balloon trawls were able to clear the stent of debris.

The remOVE cutter uses DC current for the removal of over-the-scope and fullthickness resection clips [1]. The cutting of biliary stents using an endoscopic suture cutter [2] or argon plasma beam [3] has been previously described, but this is the first reported use of the remOVE cutter to trim a biliary SEMS. We believe this is an effective method to provide endoscopic biliary access when misplaced stents prevent this and cannot be removed.

Endoscopy_UCTN_Code_CPL_1AK_2AD

\section{Competing interests}

The authors declare that they have no conflict of interest.

The authors

Tareq El Menabawey, Harry Martin, Constantinos Parisinos, Michael Chapman Department of Gastroenterology, University College London Hospitals, London, UK

\section{Corresponding author}

\section{T. El Menabawey, MD}

Department of Gastroenterology, University College London Hospitals, 250 Euston Road, London, NW1 2PG, UK telmenabawey@nhs.net 


\section{References}

[1] Caputo A, Schmidt A, Caca K et al. Efficacy and safety of the remOVE System for OTSC and FTRD clip removal: data from a PMCF analysis. Minim Invasive Ther Allied Technol 2018; 27: 138-142

[2] Levy M], Wiersema M]. Endoscopic removal of a biliary Wallstent with a suture-cutting device in a patient with primary pancreatic lymphoma. Endoscopy 2002; 34: 835-837

[3] Christiaens P, Decock S, Buchel O et al. Endoscopic trimming of metallic stents with the use of argon plasma. Gastrointest Endosc 2008; 67: 369-371

\section{Bibliography}

Endoscopy 2021; 53: E365-E366

DOI 10.1055/a-1292-4205

ISSN 0013-726X

published online 26.11.2020

(c) 2020. Thieme. All rights reserved.

Georg Thieme Verlag KG, Rüdigerstraße 14,

70469 Stuttgart, Germany

\section{ENDOSCOPY E-VIDEOS}

https://eref.thieme.de/e-videos

回回 Endoscopy E-Videos is a free access online section, reporting 靣船: on interesting cases and new techniques in gastroenterological endoscopy. All papers include a high quality video and all contributions are freely accessible online.

This section has its own submission website at

https://mc.manuscriptcentral.com/e-videos 